\title{
Eighth Award of the Henry Dunant Medal
}

The Standing Commission of the International Red Cross, at its meeting on 21 April 1983 in Geneva, decided to award the Henry Dunant Medal to seven people:

- to Dr. Mariano Bahamonde Ruiz, President of the Chilean Red Cross;

- to Mr. Hans Christian Bennetzen, delegate of the Danish Red Cross, seriously injured in the service of the League, in Uganda;

- to Professor Werner Ludwig, former President of the German Red Cross in the German Democratic Republic;

- to Dr. John Felix, League regional delegate for the Pacific and President of the Pacific Division of the American Red Cross;

- to Dr. Walter Bargatzky, former President of the German Red Cross in the Federal Republic of Germany;

- to Dr. Abdul-Aziz Mudarris, former President of the Saudi Arabian Red Crescent Society;

- to Dr. Bagus Rudiono, doctor, of the Indonesian Red Cross, who died in the service of the Red Cross in a helicopter accident on 2 April 1983 (posthumous award).

The Henry Dunant Medal is intended to constitute recognition and reward for outstanding services or acts of self-sacrifice in the cause of the Red Cross on the part of a member. It is the highest distinction conferred within the Red Cross. According to regulations it is awarded in principle to a maximum of five individuals every two years, but provision is made for the Standing Commission to reduce or to increase the number of awards in exceptional circumstances.

Instituted by the Twentieth International Red Cross Conference (Vienna, 1965) and conferred for the first time at the Twenty-first International Red Cross Conference in Istanbul in 1969, the Henry Dunant Medal has been awarded to a total of thirty-nine persons, including twelve posthumous awards. 